\title{
Analysis of consumer habits and attitudes on the Hungarian beef and rabbit market
}

\author{
Szakály, Zoltán - Szigeti, Orsolya - Szente, Viktória \\ University of Kaposvár, Faculty of Economics, Department of Marketing and Trade H-7400 Kaposvár, Guba S. u. 40. \\ e-mail: szakaly.zoltan@ke.hu
}

\begin{abstract}
As a consortium partner the authors took part in a research project aiming at the development of high added value, healthy and environment friendly animal products. From among the products developed by the consortium (rabbit meat, omega3-fatty acid enriched beef, goose liver from non forcible feeding, selenium-, vitamin-E and natural color enriched eggs) the present study describes the results concerning beef and rabbit meat. The given products are chosen because they are produced in and exported from Hungary in considerable quantities and their competitiveness can be further improved. In order to able to map the consumer preferences a 300 count nationwide, representative, questionnaire based survey was designed and performed. Actual products were tested by focus groups and professional interviews. Beside the specific features of the products a common character is that the marketing strategy focuses on the distinctive nutritional benefits and other quality parameters that seem to be of crucial importance for the targeted consumer segment. Their unique character and health protecting effects make their branding and using community labeling easy. Their positioning points toward the prestige products therefore consumers tend to accept higher prices. In marketing communication the image building advertisement can be a common goal.
\end{abstract}

Key words: beef, rabbit, consumer preferences and attitudes, nutritional benefits, consumption frequency

\section{Introducton}

Nowadays the production of special agricultural goods can be a real alternative for mass production. In our research project the focus was given on the development of high added value, healthy and environment friendly animal products and specifically our team performed the market analysis of the developed products. Our goal was to map the consumer requests, the demand as well as the main objectives of the corporate market. The results show a descriptive picture on the acceptance, attitudes and preferences concerning the given product categories. Beside revealing the requests of the target market the special research methodology offered the chance to optimize the features of the developed products. Consumer information can be paired to the marketing strategy concepts of the companies and based on that the strategy can be modified even before the introduction of the product to the market.

The primary research of rabbit and beef products focused on the analysis of consumer behaviour, the description of consumer attitudes and preferences. On the basis of the information concerning the supply and demand a general marketing strategy was elaborated for the given products.

\section{Investigation methods and materials}

During the survey 300 people were asked about their shopping habits and attitudes. The questioning happened in August 2007. Data were collected from different settlement types, including the capital, county towns, other towns and villages. The population segment above 18 years of age had equal chances to get into the panel. Due to the relatively small size of the panel the age and sex compositions of the settlements (based on 2001 statistical data) were distorted, so they were corrected by using a weight factor, therefore the survey can be regarded as a representative one both in terms of age and sex. The random walking method was combined with the so called birthday key method so the random character of the sampling was ensured. The actual data recording happened through faceto face interviews. The questionnaire contained mostly closed questions, in certain points an interval scale was applied. and scarcely free contextual answers could also be given.

Data processing was performed by SPSS for Windows 16.0. Frequency distributions, cross tables (for determining the relation of a variable to the background variables and to other involved variables) were used. Beside mean calculations significance analysis (Chi2-probe) was performed and T-probe was also used.

\section{RESULTS AND DISCUSSION}

The important results of the primary research are presented in terms of the product categories below.

\subsection{Beef and beef products}

Human nutrition biologists pointed previously out that the consumption of red meats and within them of beef should 
be reduced (Várhegyi and Várhegyiné, 2008). Today we already know that it has very valuable components which have health conditioning and positive physiological effects. Beef's essential fatty acid (linoleic acid, linolen acid) content is necessary for the evolution and normal function of the nervous system and retina that is why it is advised to pregnant and nursing mothers. Beef has a favourable polysaturated and unsaturated fatty acid proportion which plays an important role in health protection mostly because of its anti thrombosis effect (French et al., 2000). Beef has a high protein and amino acid content and taurin for babies in an easy eligible form. That is the reason for that firstly beef is added to baby food. Beef is reach in minerals like potassium, phosphorus and magnesium, but mainly it is indispensable in human nourishing of its iron and zinc content. In beef iron can be found in hemo- or mioglobulin that is why it assimilates and benefits better than the iron in plants. This specific feature of beef plays an important role in the prevention and healing of anaemia. The dietetic estimation of beef is even favourably influenced by that the anticarcinogen conjugated linoleic acid's (CLA) main source is the product of ruminant origin (Csapó et al., 2001; Schmid, 2005) and of its omega-3 and omega-6 proportion corresponds to the recommendations (Szakály S., 2004) of health support diet $(\leq 5: 1)$

Seemingly the benefits of the beef consumption caused that in 2007 as much as 52.5 million tons (in live weight) of beef were consumed around the world which is $0.5 \%$ higher than that of the previous year value (Agroinform, 2008). In the European Union - mostly in the Western countries - the relatively high per capita consumption of $20 \mathrm{~kg} / \mathrm{head}$ seems to persist (Agrár Európa, 2005). In Hungary between 1970 and 1980 the per capita beef and veal consumption was $10 \mathrm{~kg}$ followed by a drop back to $4.3 \mathrm{~kg} / \mathrm{head}$ by 2000 . The 2006 year data showed only $3.1 \mathrm{~kg} /$ head (KSH, 2007).

The questionnaire survey showed that 8 consumers out of ten $(82 \%)$ used to eat beef or beef products with certain frequencies. Men eat beef more often. People who do not eat beef usually state that they do not like the taste or beef is out of their nourishment habits and most of them do not tend to eat it in the future. Those who would consume it in the future indicated a lower price as a motivation. As for beef the consumption frequency of dishes made of cuts (roast, shank, sirloin etc.) and the beef products (salami, stuffed products). Results are shown in Table 1.

Table 1. Consumption frequency of beef and its products among consumers $(\mathrm{N}=245)$

\begin{tabular}{|l|c|c|c|c|}
\hline \multirow{2}{*}{ Frequency } & \multicolumn{2}{c|}{ Carcase meat } & \multicolumn{2}{c|}{ Beef product } \\
\cline { 2 - 5 } & Head & $\%$ & Head & $\%$ \\
\hline Every day & 0 & 0.0 & 1 & 0.4 \\
\hline 2-3 times a week & 20 & 8.2 & 29 & 11.8 \\
\hline 2-3 times a month & 108 & 44.1 & 92 & 37.6 \\
\hline Every other month & 61 & $24.9 \%$ & 31 & 12.7 \\
\hline Rarely than every other month & 56 & $22.9 \%$ & 48 & 19.6 \\
\hline Never & 0 & $0.0 \%$ & 41 & 16.7 \\
\hline Do not know/Do not answer & 0 & $0.0 \%$ & 3 & 1.2 \\
\hline
\end{tabular}

Cut dishes occur on the table of most answerers 2 or 3 times a week. The average consumer buys them more rarely, not even on one occasion per month. Beef products are consumed far more rarely by people.

The answerers were asked to determine how much they agree with the statements on a 5 range scale $(1-$ do not agree, 5 - agree). The evaluation is showed in Table 2 .

Table 2. Consumer judgement of beef ${ }^{1}$ $(\mathrm{N}=300)$

\begin{tabular}{|l|c|c|c|}
\hline \multirow{2}{*}{ Statement } & \multicolumn{3}{|c|}{$\begin{array}{c}\text { More important statistical } \\
\text { data }\end{array}$} \\
\cline { 2 - 4 } & N & Average & $\begin{array}{c}\text { Standard } \\
\text { deviation }\end{array}$ \\
\hline Beef is healthier than pork. & 278 & 4.23 & 0.98 \\
\hline Beef is expensive compared to other meats. & 272 & 4.11 & 0.89 \\
\hline I look for quality when I buy beef. & 284 & 4.04 & 1.16 \\
\hline I would buy more if beef was cheaper. & 297 & 3.51 & 1.51 \\
\hline Beef includes conjugated linoleic acid (CLA). & 119 & 3.47 & 1.06 \\
\hline $\begin{array}{l}\text { Frequent consumption of beef helps to } \\
\text { prevent cancer. }\end{array}$ & 177 & 2.97 & 1.34 \\
\hline
\end{tabular}

${ }^{11} 1=$ Don't agree at all ... 5= Totally agree)

The panel agreed mostly with the statement saying that beef is healthier than the pork (4.23). However, they do not seem to know at all that beef products are rich in conjugated linolic acids which can be traced back to the fact that they do not know anything about fatty acids. It comes out that they do not know (2.97) the most important anticarcinogenic effect of multiple unsaturated fatty acids. The price of beef is considered to be high, especially when compared to other meat types. It turns out, however, that price reduction alone would not be able to raise the consumption level.

The analyses of the attitudes against the beef showed that most consumers do not have any idea about the conjugated linolic acid (CLA) content (and therefore cancer preventing effects) of the beef. As a summary it can be stated that most Hungarian consumers do not buy red meats because of their taste and price.

\subsection{Rabbit meat}

Rabbit meat has low fat and cholesterol level, high protein content ad it is especially rich in some vitamins and minerals. The cholesterol level and fat content of rabbit is lower than that of poultry, turkey, beef or pork. Another benefit of rabbit meat is that its unsaturated fat content reaches $63 \%$ among all tats, and the ratio of n-6 and n-3 fatty acids is 7,4-7,5, which is advantageous from nutritionalbiological point of view (Lugasi, 2007).

In spite of its nutritional benefits the consumption per inhabitant in Hungary hardly reaches $0,1 \mathrm{~kg}$ per year (Szendrö, 1998, Tanai, 2007). Almost the total quantity of the rabbits bred in the country is exported to Italy, Switzerland, France, Belgium) (Lugasi, 2007). Surveys - apart from one or two - to find the reasons for the low consumption have not yet been made in Hungary, but at the same time two 
influencing factors are evident: only a tiny part of the produced meat reaches the Hungarian retailers (Bodnár et al., 2003) and partly due to this rabbit meat consumption has no traditions in Hungarian dining culture.

The countrywide survey showed that $31 \%$ of the people involved in the panel used to consume rabbit meat and such products with certain frequencies. Among people living in the less populated settlements the rabbit meat consumption is more frequent than in other areas (the peak values are $40 \%$ in villages, and $16 \%$ in the capital).

What are the motives of $207(69 \%)$ people in the panel who do not eat rabbit meat at all? About one third of the consumers $(41.5 \%)$ do not like its taste and $29 \%$ said that rabbit meat was out of the range of their dietary habits. If the two categories were aggregated, the result would show that the rejection of rabbit meat comes from bad preconceptions, attitudes, misbelieves and habits. Some $91.3 \%$ of them would not see a chance for consuming rabbit meat in the future.

It is an additional problem that even in the case of rabbit eaters the consumption frequency is quite low as it is shown in Table 3.

Table 3. Consumption frequency of rabbit meat among consumers (N=93)

\begin{tabular}{|l|c|c|}
\hline \multirow{2}{*}{ Frequency } & \multicolumn{2}{|c|}{ Division of answers } \\
\cline { 2 - 3 } & Head & \% \\
\hline Every day & - & - \\
\hline 2-3 times a week & 2 & 2.2 \\
\hline 2-3 times a month & 14 & 15.1 \\
\hline Every other month & 21 & 22.6 \\
\hline More rarely than every other month & 56 & 60.1 \\
\hline
\end{tabular}

The results point out that most people consume rabbit meat once $(22.6 \%)$ or less than once $(60.1 \%)$ in every two months. Therefore it is not surprising that rate of more frequent consumption is very low (17.3\%), daily usage is not observable.

Most people buy rabbit meat at the local market directly from the producer $(29 \%)$ or in special shops $(21.5 \%)$ and the rate of own production is remarkable $(28 \%)$.

Table 4. Consumer judgement of rabbit meat ${ }^{1}(\mathrm{~N}=300)$

\begin{tabular}{|l|c|c|c|}
\hline \multirow{2}{*}{ Statement } & \multicolumn{3}{|c|}{$\begin{array}{c}\text { More important } \\
\text { statistical data }\end{array}$} \\
\cline { 2 - 4 } & N & Mean & $\begin{array}{c}\text { Std. } \\
\text { deviation }\end{array}$ \\
\hline Rabbit meat has low fat content. & 229 & 4,22 & 0,88 \\
\hline $\begin{array}{l}\text { Rabbit meat has lower fat content than } \\
\text { poultry. }\end{array}$ & 213 & 4,13 & 0,97 \\
\hline Rabbit meat has low cholesterol content. & 203 & 4,01 & 0,98 \\
\hline $\begin{array}{l}\text { Rabbit meat is expensive compared to } \\
\text { other meats. }\end{array}$ & 200 & 3,94 & 1,05 \\
\hline Rabbit meat has low calorie content. & 209 & 3,90 & 0,98 \\
\hline $\begin{array}{l}\text { Rabbit meat has a favourable n-6/n-3 fatty } \\
\text { acid rate. }\end{array}$ & 138 & 3,62 & 1,00 \\
\hline I would by more if rabbit meat was cheaper. & 263 & 2,55 & 1,55 \\
\hline $\begin{array}{l}\text { I would buy more if rabbit meat was } \\
\text { available everywhere. }\end{array}$ & 269 & 2,55 & 1,61 \\
\hline
\end{tabular}

${ }^{1} 1$ =Don't agree at all ... 5=Totally agree
The attitudes concerning rabbit meat are shown in Table 4 .

The results are favourable on the one hand and quite reminding on the other. The panel agreed mostly with the fact that rabbit meat has low fat content and that is true when compared to other meat types, mainly with pork and beef. The result is important because - through effective marketing communication - it can be fitted into the frames of healthy nutrition. Many people think that rabbit meat has lower fat content than that of the poultry and many consumers associate low fat levels with low cholesterol and energy contents, so the position of the product is very favourable. The positive product image is indicated by low deviation values. Lack of knowledge and poor community marketing efforts are indicated, however, by the fact that in case of omega-6/omega-3 fatty acid content the rate of uncertain answers is extremely high $(54 \%)$.

A part of the panel representatives agreed upon the fact that the price of rabbit meat is high compared to other meat types. It can be a serious marketing challenge for the companies entering the Hungarian market that the customers are obviously unmotivated in buying rabbit meat. About half of them would not buy more of it even at lower prices. It means that no discount campaigns could help, and it would not help either if the product was available more widely.

As a summary it can be concluded that biggest part of the Hungarian consumers failed to know the characteristics of rabbit meat, many of them had not even eaten it yet, therefore their judgments did not based on own experiences.

\section{Conclusions and proposals}

Market analysis of the investigated products showed that rabbit meat and beef belong to the products of special niche markets and through their health conditioning features their marketing can be placed on common strategic bases. It turned out that to define the target market the concentrated, unisegmental marketing is applicable. Practically it means segment targeting (both in Hungary and abroad) with higher income levels.

The positions of the products are described by the followings: highest quality level (in strict sense of the word), unique character, well identifiable product features. The taste and organoleptic value of the products are excellent accompanied by health conditioning functions. The direction of marketing activities is defined by the latter points, namely beside the health conditioning function the special character should be emphasized.

Marketing tools under the product strategy can be: identifiable branding strategy, aesthetic and attractive packaging, unique product features, target group specific quality characters. The central element of the strategy (for both product categories) on the Hungarian and foreign markets is the high quality (and health conditioning) branded product accompanied by aesthetic packaging and high organoleptic value. Both product categories have all the necessary and advantageous features to become successful on the markets. 
Taking this position in the foreground, the direction of pricing in case of rabbit and beef products can point only toward the prestige categories both on domestic and on foreign markets. The pricing should be demand driven, namely the basis of the price is the level still accepted by the customers. The other elements of the marketing mix (community marketing, branding, high quality level) serve to make the potential markets accept the higher price level. It is obvious that due to the high prices the products in concern will be the foodstuffs of certain market niches.

It is no doubt, that the high price and quality level products should be sold in retail units where the customers of the higher income segment appear frequently. Since the beef and rabbit products are rather niche foodstuffs beside the hyper- and supermarkets the exclusive retail units (delicate shops, special butcheries, restaurants, luxury hotel chains etc.) should also be targeted. Enlisting in exclusive retail chain can be expected mostly on foreign markets.

The key factor of the market distribution of the two product categories is the rational design of the integrated communication. In Hungary already appeared a smaller group of consumers being clear with the values and nutritional benefits delivered by certain foods. Community marketing has a central role in promoting the products. Wider occurrence of the products in concern requires new concepts in community marketing focusing on own labeling, forming of regional labeling groups and protection of origin. An effective marketing communication has to be present in the tourism as well. Remarkable profits can be gained through hosting, catering (dishes, garnishes, recipes) even supported by (after effective programming) the different community marketing organizations.

\section{Acknowledgement}

The support of the National Research and Development Plan (NKFP 4/024/2004) is gratefully acknowledged.

\section{References}

Szakály Z., Szigeti O., Szente V.: Hagyományos magyar termékek marketinglehetőségeinek elemzése a vidékfejlesztés szempontjainak figyelembevételével. (In Inotai (szerk): EU-Tanulmányok V., 1-696.) Tas Kiadó, Budapest, 2004. 465-498.

Várhegyi J-né, Várhegyi J.: A marhahús megítélése humán egészségügyi szempontból. „Komplex EU konform húsmarha-tenyésztés fejlesztési rendszer" c. pályázat összefoglalója

Tarrant, P.V.: A future for beef. Proceedings of the 57th Annual Reciprocal Meat Science Association Lexington, Kentucy, 2004, $1-6$.

Schmid, A.: CLA- ein Fleischbestandteil mit positiven Gesundheitswirkungen. Metzger und Wurster (5) 1-4 (2005)

Csapó J., Vargáné Visi É., Csapóné Kiss Zs., Szakály S.: Tej és tejtermékek konjugált linolsav-tartalma III. A konjugált linolsavak és a tejzsír biológiai hatása; kojugált linolsavak az emberi szervezetben. Acta Agraria Kaposváriensis 5 (4) 1-12 (2001)

Szakály S.: Táplálkozási dilemmák és az élelmiszerek fejlesztésének világstratégiai irányai. Élelmiszer, táplálkozás, marketing 1 (1-2) 15-24 (2004)

Holló G.: Hagyományos állatfajták húsának zsírsavösszetétele és humán-élettani megítélése. Élelmiszer, táplálkozás és marketing 1 (1-2) 63-72 (2004)

Simopoulos, A. P.: Omega- 3 fatty acids in health and disase and in growth and development. A. J. Clin. Nutrition 54 438-463 (1991)

www.elelmezes.hu: Horváth É, Johan B.: Módszertani levél a tojással és tojásalapú készítményekkel kapcsolatos élelmiszerbiztonsági szabályokról.

Zajkás G.: Magyarország Nemzeti Táplálkozáspolitikája. 1-32. Budapest (2004) 